\title{
THE OUTWASH PLAIN OF THE ROSPUDA RIVER VALLEY - A RECORD OF DEPOSITIONAL ENVIRONMENTS
}

\author{
Katarzyna Pochocka-Szwarc ${ }^{1}$, Dariusz Krzyszkowski ${ }^{2}$ \\ ${ }^{1}$ Polish Geological Institute - National Research Institute, Warszawa, \\ katarzyna.pochocka-szwarc@pgi.gov.pl \\ ${ }^{2}$ Institute of Geography and Regional Development, University of Wrocław, Pl. Uniwersytecki 1, \\ 50-137 Wrocław, dariusz.krzyszkowski@ing.uni.wroc.pl
}

\begin{abstract}
The Rospuda subglacial channel hosts not only deep ribbon lakes and the Rospuda River itself, but also an outwash plain. The paper deals with a lithofacies analysis of deposits from exposures within the Rospuda outwash plain. With the support of geomorphological and geological analyses, it has been found that the outwash plain formed along the Rospuda subglacial channel that was being exposed from under the ice cover.

The lithological record of the Rospuda outwash plain shows a distinct division into a proximal and a distal zone. The deposits under study reveal a record of a break in basial sedimentation, when ice-wedge casts developed under conditions of periglacial climate. The development of the Rospuda outwash plain is linked with the ice-marginal zone of the Pomeranian phase, similarly to the Olecko-Rajgród outwash plain that is located to the west.
\end{abstract}

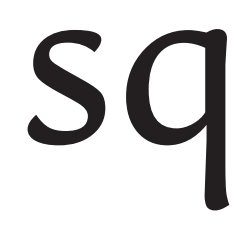

Key words: Rospuda River, subglacial channel, valley outwash plain, lithofacies analysis, ice-sheet limits.

Manuscript received 17 June 2015, accepted 17 November 2015

\section{INTRODUCTION}

The sites, presented in this paper, were analysed during geological-mapping work for the preparation of the DGMP, scale 1:50,000, conducted in the 1990s. The work included investigations of exposures within the Rospuda outwash plain, located along the Rospuda River valley crossing the map sheets of Olecko (Bruj and Woźniak, 1991) and Augustów (Ber, 1991, 2007) of the DGMP, scale 1:50,000. As moving from the north to the south, the following exposures have been studied: Garbaś and Szafranki, Bakałarzewo, Raczki Małe, Choćki, Szkocja and Chodorki as well as and the southernmost site of Szczebra (Fig. 1). These are both natural (Rospuda River scarps) and artificial exposures. In order to identify the type of sedimentation and to relate the deposits to end moraine zones, lithofacies analysis of the deposits from the documented sites has been performed.

The Rospuda outwash plain, Rospuda River valley and the above-mentioned lakes occur within a NW-SE-trending subglacial channel. The total length of the channel is approximately $40 \mathrm{~km}$.

The outwash plain and the Rospuda River valley are situated in a zone developed during the Pomeranian phase of the Main Stadial of the Vistulian Glaciation (Ber, 1974, 1989, 1991; Lisicki, 1993; Marks et al., 2006). The subglacial channel is filled with glaciofluvial deposits attaining a thickness from $17 \mathrm{~m}$ (Bruj and Woźniak, 1991) to $10 \mathrm{~m}$ (Ber,
2007) and forming the so-called Rospuda outwash plain (Ber, 1974, 1989, 1991) merging (near Augustów) with the Suwałki-Augustów outwash plain.

\section{STUDY AREA}

The study area is located in NE Poland within the Podlasie Voivodeship. The Rospuda River valley and the Rospuda outwash plain are situated in the Western Suwałki Lakeland. Within the outwash plain area, the Rospuda River flows through nine lakes of the following maximum depths: Rospuda Filipowska (38.9 m), Długie (9 m), Garbaś (48 m), Głębokie $(16 \mathrm{~m})$, Sumowo $(12.8 \mathrm{~m})$, Okragke $(3.8 \mathrm{~m})$ and Bolesty $(16.2 \mathrm{~m})$, and then flows to Rospuda Augustowska Lake (10 m) near Augustów.

\section{GEOLOGICAL SETTINGS}

The present-day relief has been developed as a result of both erosional and depositional activity of the last ice sheet during the Vistulian Glaciation, and subsequent deglaciation processes. The Rospuda River valley is situated in the area covered by an ice sheet during the Pomeranian phase of the Main Stadial of the Vistulian Glaciation. The Rospuda River valley follows the NW-SE-trending subglacial channel.

The Rospuda subglacial channel was formed as a result of subglacial erosion during earlier stadials of the Vistulian 


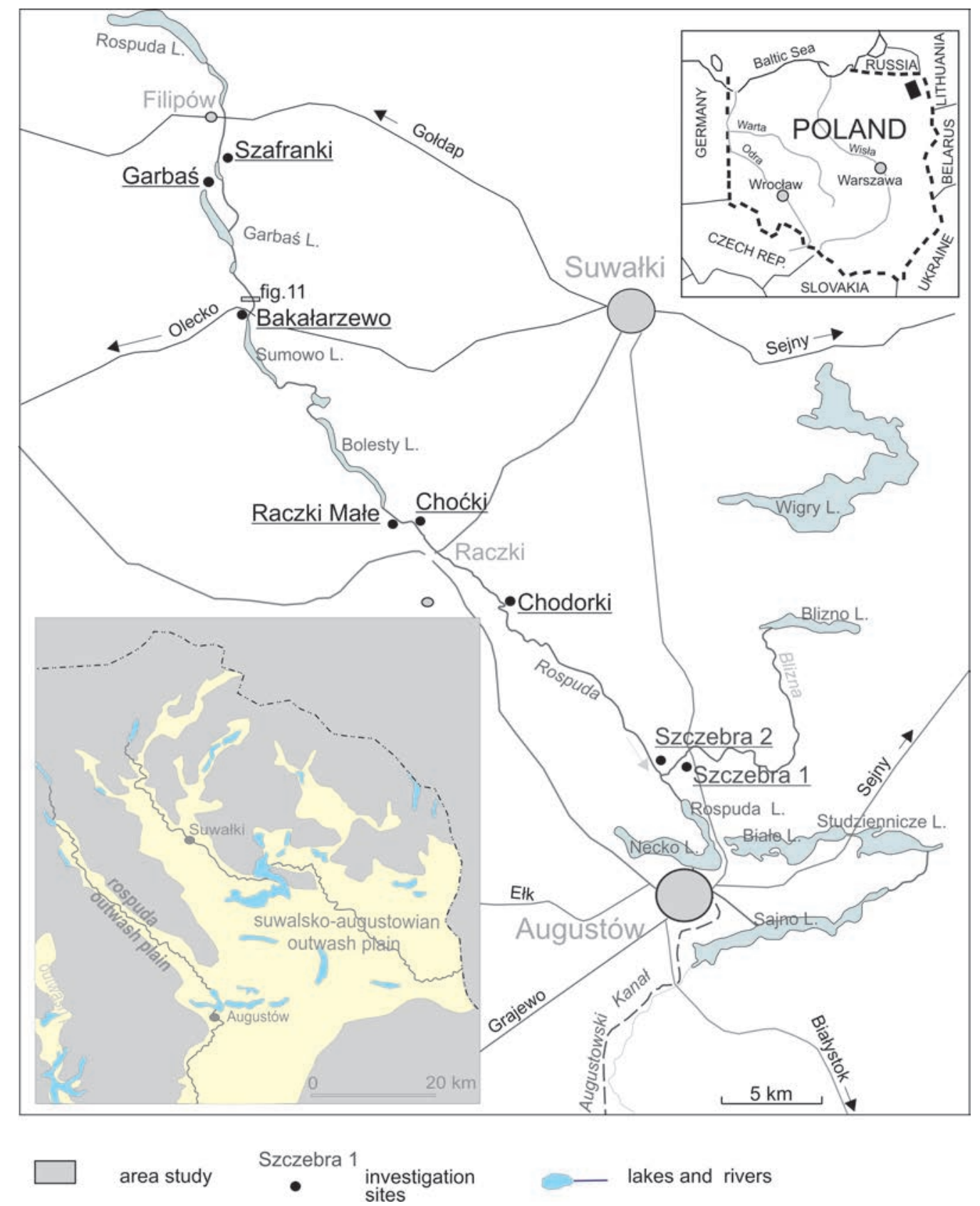

Fig. 1. Location of the sites studied.

Glaciation. It is filled with glaciofluvial deposits composing the outwash plain itself (as well as accumulation landforms, such as eskers and crevasse fills). There are also ribbon lakes and the Rospuda River within the subglacial channel. The channel floor is situated at elevations ranging from $168 \mathrm{~m}$ a.s.l. (near Szafranki) to $150 \mathrm{~m}$ a.s.l. near Lake Bolesty. The channel's edges are most offen commonly from 10 to $15 \mathrm{~m}$ in height, with a maximum of 37.5 m near Bakałarzewo (Bruj, Woźniak 1991). The subglacial channel is cut into the moraine upland surface covered by, e.g., end moraines (west of Lake Garbaś). Along its edges, and locally at the bottom, eskers and crevasse-fill landforms are observed and they are arranged parallel to the channel axis (from NW to SE) (Fig. 2). There are also so-called side channels, e.g. a subglacial channel located east of Lake Bolesty. The occurrence of these ero- sional landforms may suggest migration of subglacial flow in the channel (Bogacki, 1976).

The thickness of Rospuda outwash plain deposits in the channel is approximately $10-17 \mathrm{~m}$. The width of the outwash plain in the narrowest place is about $0.5 \mathrm{~km}$, whereas in the widest place it varies from 4 to $5 \mathrm{~km}$. The Rospuda outwash plain trail is divided into two morphologically different sections: the northern section and the southern section. The former runs from the river sources through the lakes of Czarne, Rospuda Filipowska, Garbaś, Sumowo and Bolesty (Bogacki, 1976). In this section, the outwash plain deposits do not form a continuous level but they occur only in areas of channel widening, e.g. near Lake Garbaś. Glaciofluvial deposits of this section form two terrace levels. The upper terrace $(\mathrm{I}-$ older one) is at elevations of $197-170 \mathrm{~m}$ a.s.l. The 


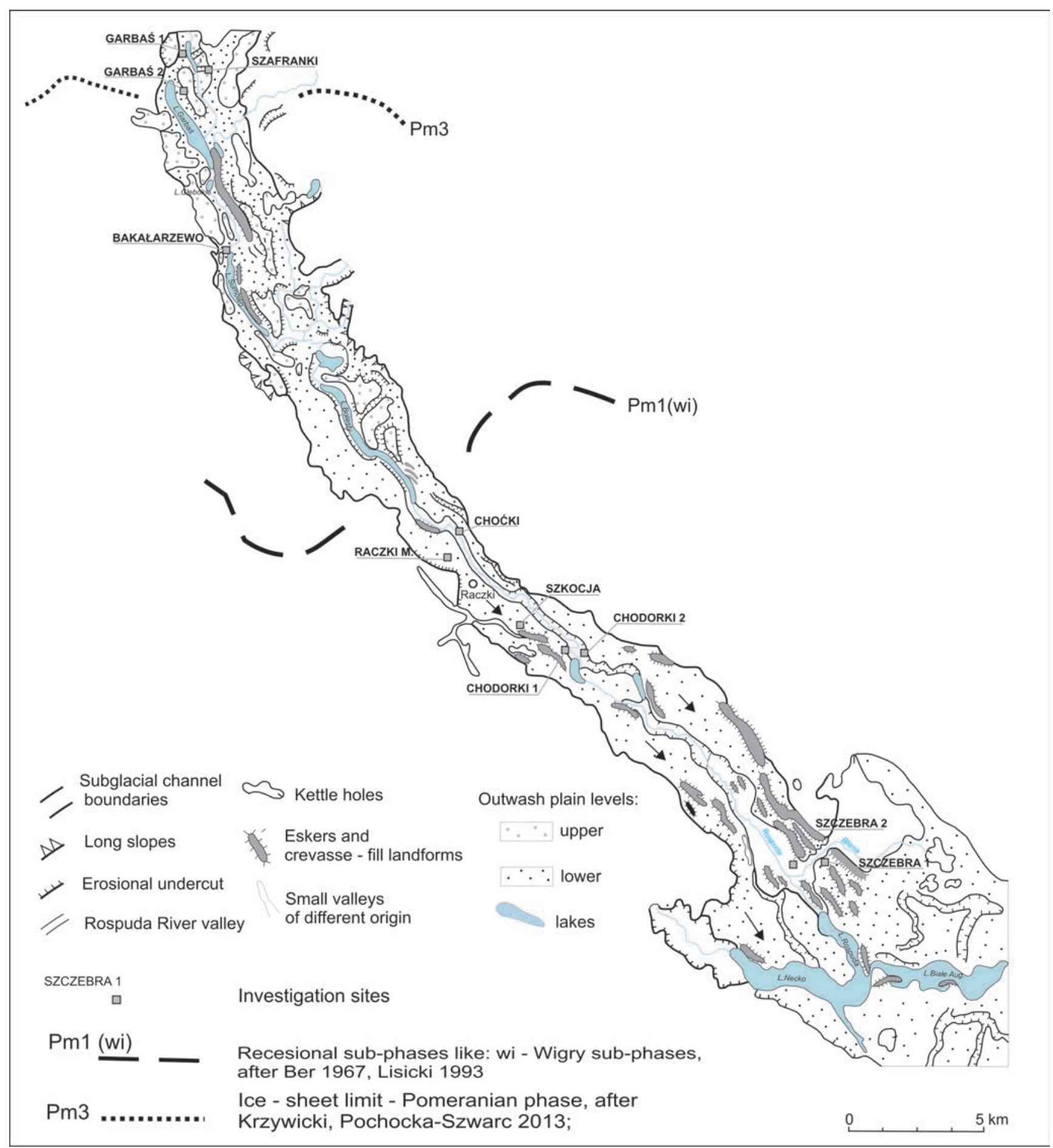

Fig. 2. Geomorphological sketch-map of the Rospuda River valley, based on Ber (2007).

lower terrace (II - younger one) occurs at elevations of $187-$ $167 \mathrm{~m}$ a.s.l. (Bruj and Woźniak, 1991).

The other, southern section is located to the south of Lake Bolesty (Bogacki, 1976), where the outwash plain trail is much wider and situated at elevations of 165 down to 130 m a.s.l. Near Augustów, the Rospuda outwash plain joins the extensive Suwałki-Augustów outwash plain (Ber, 2007). The topography of the Rospuda outwash plain is featured by endorheic depressions, often arranged parallel to the valley axis, i.e. from NW to SE. In the area located south of Raczki, there are numerous crevasse-fill landforms rising above the outwash plain surface (Ber, 2007).

The Rospuda River flows towards the southeast in a locally well-developed valley incised into the outwash plain deposits. In the southern part of the Rospuda valley, there is an extensive peat bog filling a widening in the valley, and being a relic of pre-existing lake's channel (Ber, 2007). 


\section{Garbaś 1}
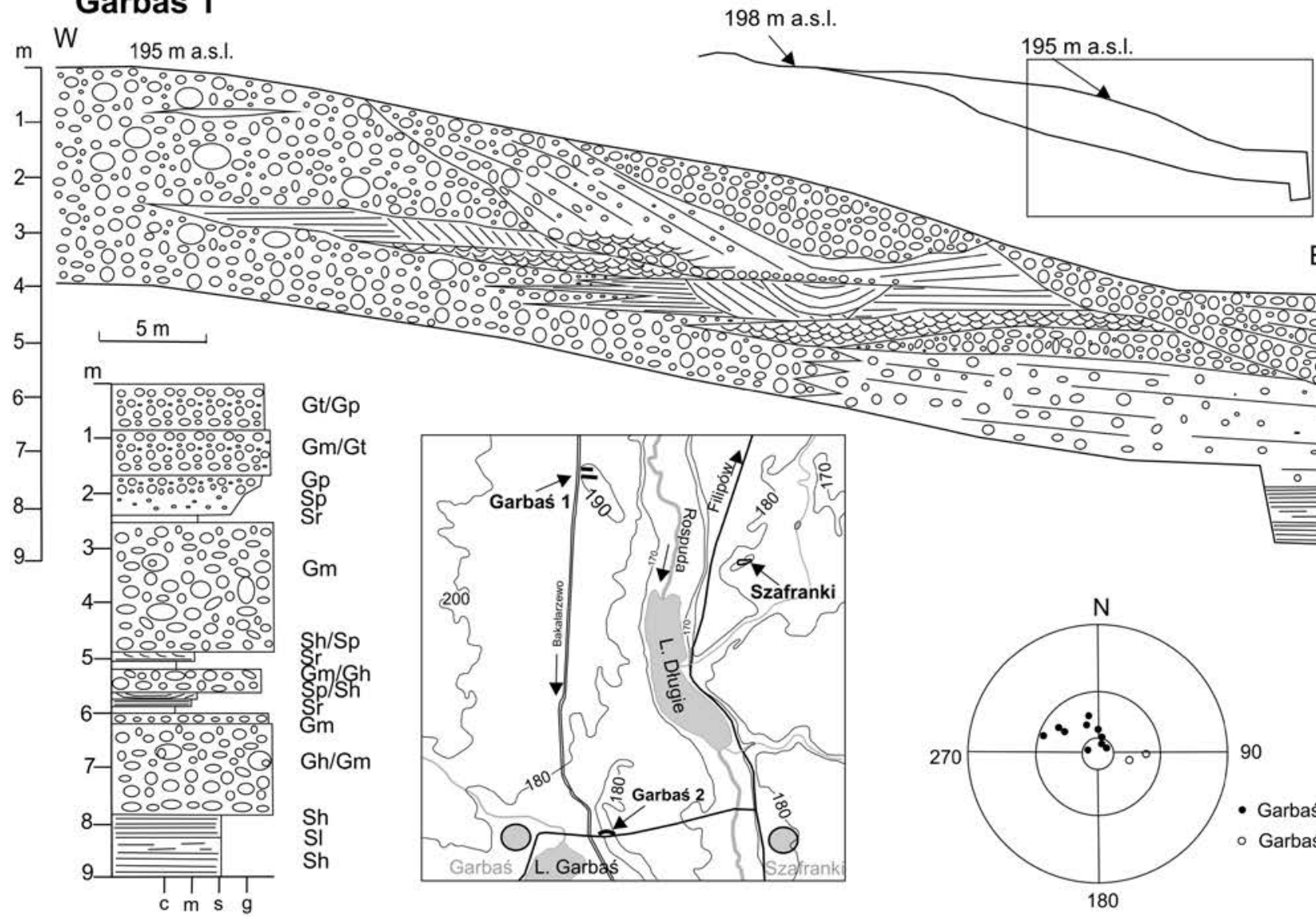

E

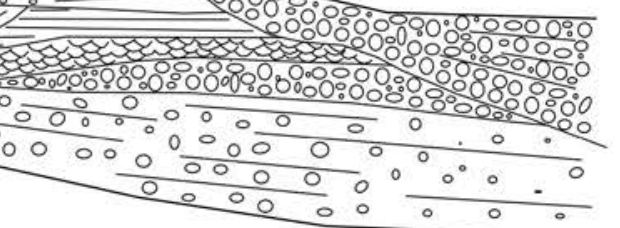

\section{Garbaś 2}
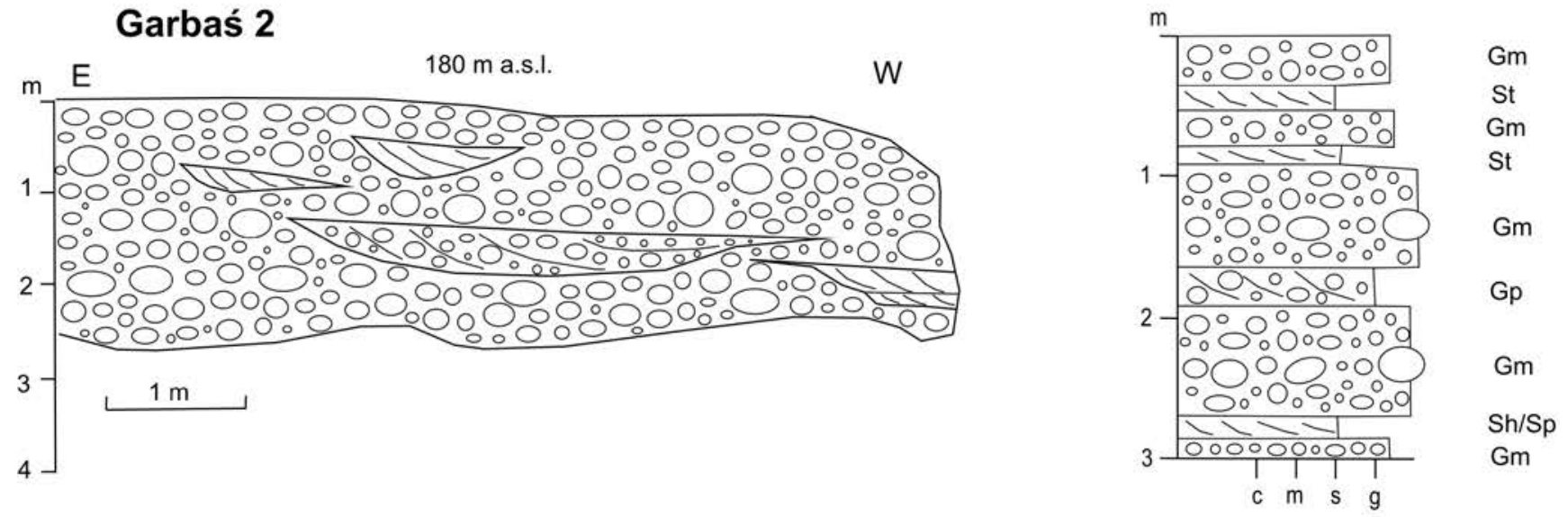

Szafranki 1
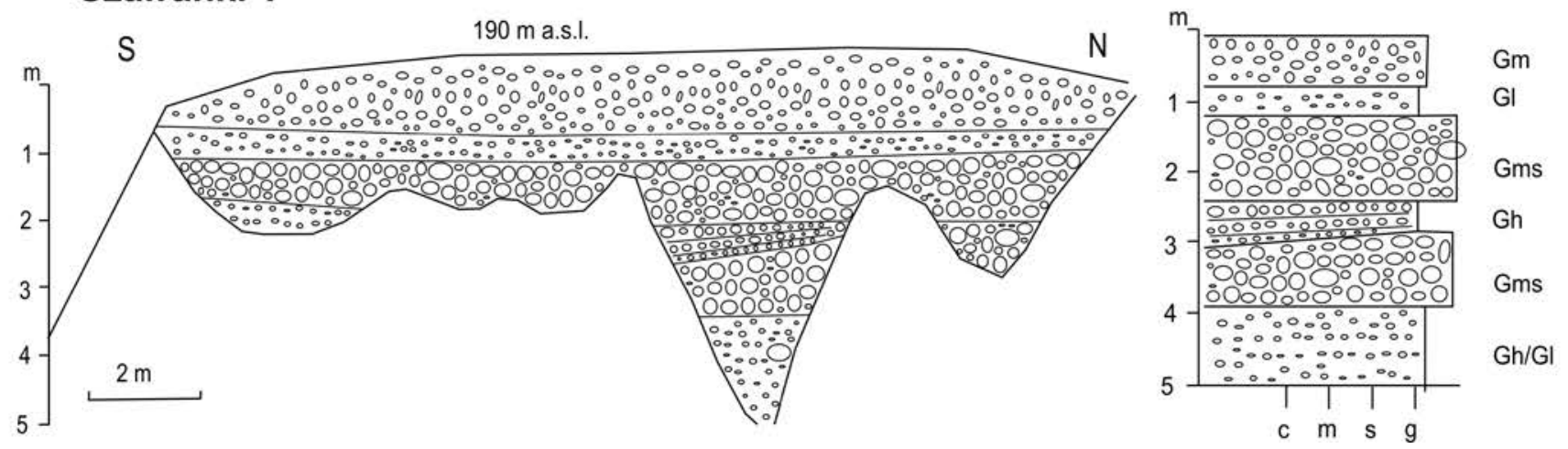


\section{METHODS}

In order to reconstruct the sedimentary conditions during outwash plain deposition, 11 exposures were examined along the outwash plain trail. These are, from north to south: Garbaś 1 and 2, Szafranki, Bakałarzewo, Raczki Małe 1 and 2, Choćki, Szkocja and Chodorki, as well as the southernmost exposures of Szczebra 1 and 2 (Fig. 2). For each site, sketch-drawings of exposed walls, and lithological logs were made. Orientations of long axes of pebbles were also measured. The lithological interpretation has been adapted owing to Miall $(1977,1996)$ and modified by Zieliński (1993) and Krzyszkowski (1993).

\section{SEDIMENTOLOGICAL INTERPRETATION OF SITES}

\section{Szafranki site}

The northernmost site of Szafranki is located south of Lake Rospuda Filipowska, near the eastern boundary of the outwash plain (190 m a.s.1.). Massive, grain-supported coarse sediments (sands and gravels), horizontally bedded coarse-grained sands and gravels are observed in this area (Fig. 3).

\section{Garbaś sites}

Two sites were examined: Garbaś 1 located near the road from Filipowo to Bakałarzewo, and Garbaś 2 situated on the northern shore of Lake Garbaś. Part of the exposure is illustrated in Fig. 4.

Garbaś 1. Large-scale gravelly lithofacies: bedded gravels and massive gravels with small admixture of horizontally laminated sands. The top of these deposits occurs at an elevation of $195 \mathrm{~m}$, which is the highest elevated site studied (Fig. 3).
Garbas' 2. The exposure is located on the northern shore of Lake Garbaś (180 m a.s.l.) and is represented by similar lithologies to those from Garbas 1 , with predominance of massive, grain-supported medium- and coarse-grained gravels (Fig. 3).

Interpretation. The sites of Szafranki and Garbaś 1 and 2 reveal deposits accumulated near the ice-sheet terminus in the proximal zone of braided channel, which may represent longitudinal bars. They were deposited in high-energy flow environments close to the recharge source.

The deposits from both Garbaś and Szafranki (Fig. 3) represent lithotype characteristic of a proximal braided stream, accumulated in a channel with longitudinal gravel bars (Zieliński, 1993).

\section{Bakalarzewo site}

A gravel-pit located at Bakałarzewo, near the SuwałkiOlecko road, north of Lake Sumowo (Fig. 5). The characteristics of profiles exposed in four walls (A, B, C and D) have been given (Fig. 5). The top layer is composed of cross-bedded gravels (series A), locally with larger boulders Fig. 6. The total thickness of the series is about $4 \mathrm{~m}$. The gravels are underlain by deposits of series B, proving a different sedimentary environment. These are muddy-sandy and sandy sediments with ripple marks, separated by two gravel pavement horizons. The top of series B occurs at an elevation of $166 \mathrm{~m}$ a.s.l. There are two horizons of ice-wedge casts in the fine-grained basinal deposits, each approximately $0.5 \mathrm{~m}$ long. They are overlain by horizontally laminated sands and ripple-laminated sands.

Interpretation. Series A from Bakałarzewo proves deposition in a braided river with relatively small bars. Sediment transport was fast and cyclic, occurring relatively close to the

\section{LITHOLOGY}

\begin{tabular}{|c|c|}
\hline 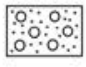 & $\begin{array}{l}\text { massive, matrix-suported (Gms) } \\
\text { gravel }\end{array}$ \\
\hline 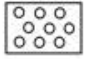 & massive gravel $(\mathrm{Gm})$ \\
\hline & $\begin{array}{l}\text { trough cross-bedded }(\mathrm{Gt}) \\
\text { gravel }\end{array}$ \\
\hline & $\begin{array}{l}\text { planar cross -bedded (Gp) } \\
\text { gravel }\end{array}$ \\
\hline & $\begin{array}{l}\text { horizontally bedded (Gh) } \\
\text { gravel }\end{array}$ \\
\hline \begin{tabular}{|l|l|}
$\frac{0}{0} 00$ \\
$0 \% 00$
\end{tabular} & $\begin{array}{l}\text { very fine to coarse, }(\mathrm{GI}) \\
\text { massive gravel }\end{array}$ \\
\hline 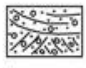 & $\begin{array}{l}\text { trough cross-bedded (GSt) } \\
\text { sand \& gravel }\end{array}$ \\
\hline 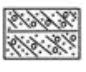 & $\begin{array}{l}\text { planar cross-bedded (GSp) } \\
\text { sand \& gravel }\end{array}$ \\
\hline 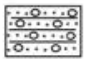 & $\begin{array}{l}\text { horizontally bedded (GSh) } \\
\text { sand \& gravel }\end{array}$ \\
\hline
\end{tabular}
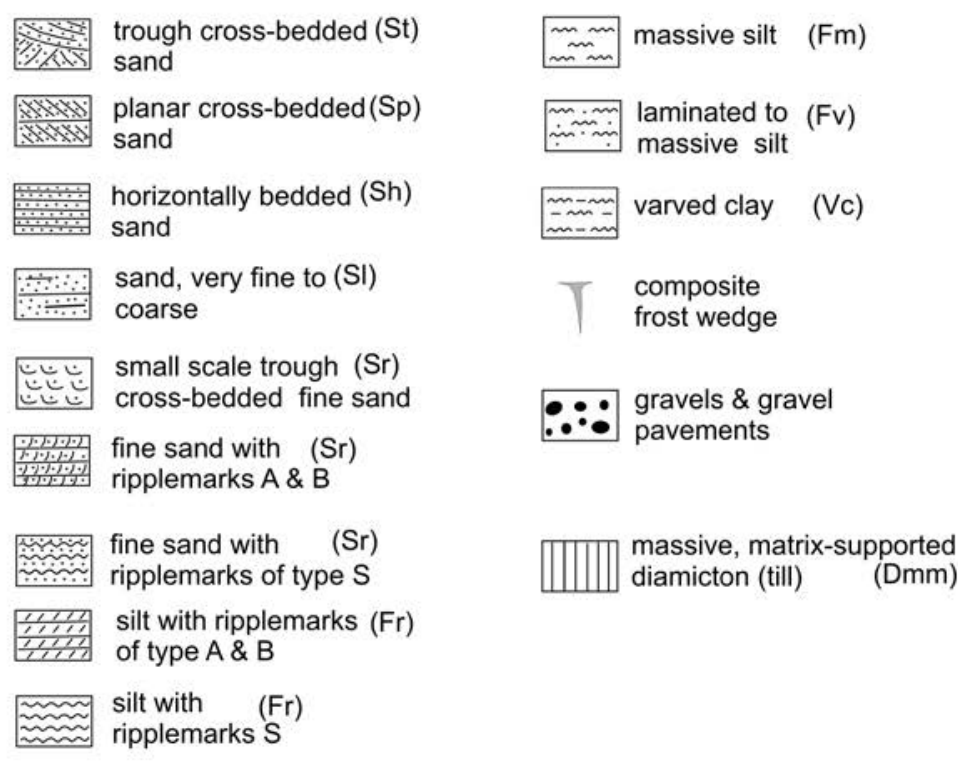

Fig. 3. Location of the Szafranki and Garbaś sites, and the sketch-drawings of exposed walls. Explanation of lithological signs and symbols (applied to all sites described). 


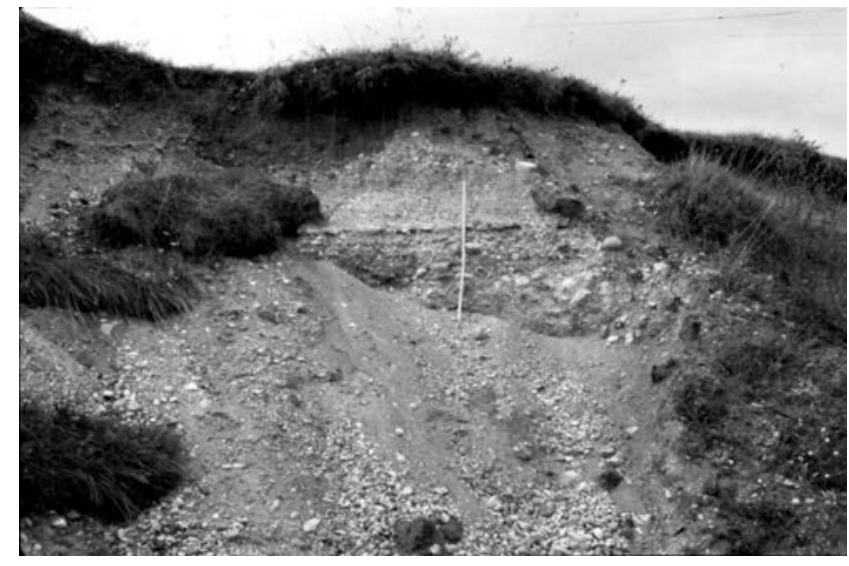

Fig. 4. The Garbaś site exposure. Photo by D. Krzyszkowski.

recharge source represented by the ice-sheet front. Deposits of this series can represent lithotype characteristic of proximal braided stream - accumulated in a channel with large river-bed scours and megaripples (Zieliński 1993).

Series B represents overbank facies which emerged above the water level. Then, in periglacial conditions and in the presence of permafrost, a favourable environment for ice wedge formation existed on the exposed surface.

\section{Raczki Małe sites}

These are two exposures located north of the village of Raczki, in the Rospuda River valley.

Raczki Mate 1 is an exposure of erosional undercut in the present-day river bank (Fig. 7). The exposure reveals trough cross-bedded sands (4 m thick) with small admixture of horizontally laminated sands, and cross-bedded gravels at the top. The top surface of these deposits is situated at an elevation of $160 \mathrm{~m}$ a.s.1.

Raczki Mate 2 is an exposure of ancient erosional undercut, distant from the present-day river bank. The thickness of deposits observed in this exposure varies from 3.5 to $5 \mathrm{~m}$. The top surface occurs at an elevation of $153 \mathrm{~m}$ a.s.l. Coarsegrained sediments are dominant here: cross-bedded gravels and massive gravels, with small admixture of trough crossbedded sands (Fig. 7).

Interpretation. The deposits were accumulated under concentrated flow conditions that facilitated deposition of longitudinal bars. The dominant transport directions were from the east. Deposits from Raczki Małe, like those of series A from Bakałarzewo, can be correlated with lithofacies characteristic of the environment of proximal braided channel (Zieliński, 1993).

\section{Choćki site}

The exposure is located southeast of Lake Bolesty, near the eastern boundary of the Rospuda outwash plain (Fig. 8). The thickness of the observed deposits is $2.5 \mathrm{~m}$. The top of series $\mathrm{A}$ is situated at an elevation of $157 \mathrm{~m}$ a.s.l. The series is represented by medium- and large-scale trough-bedded gravels and sands. They are underlain by horizontally laminated sands separated by massive gravels with the observable thickness of approximately $0.5 \mathrm{~m}$, referred to as series B. The top of series B is at an elevation of about $155 \mathrm{~m}$ a.s.1.

Interpretation. Deposits of series A from Choćki represent sedimentation under concentrated flow conditions. They can be compared with lithotype (Zieliński, 1993) accumulated in an environment of relatively deep channel with large river-bed scours. Series B documents calm flow conditions interrupted by episodes of more intensive, dynamic flow (upper planar bed). Series A from Choćki can be correlated with series A from the Raczki Małe and Bakałarzewo sites.

\section{Szkocja site}

This exposure is located south of the village of Raczki, near the Augustów-Raczki road close to the western boundary of the outwash plain (Fig. 9). Two walls have been described: A and B (Fig. 9).

The observed thickness of deposits ranges from $3.5 \mathrm{~m}$ to $6 \mathrm{~m}$ (Fig. 9). The section is represented by trough-bedded sands and gravels (series A). Deposition took place in a relatively deep channel with intensive flows facilitated the formation of megaripples (Zieliński, 1993). This series is underlain by fine-grained sediments deposited in a low-energy environment (series B). There were also episodes of material supply by higher-energy flows. It is evidenced by the presence of horizontally bedded gravels. At least four such cycles can be identified within this section. The boundary between series A and series B is erosional in nature (Fig. 9).

Interpretation. Series A was probably formed in a gravel-bed braided river under concentration flow conditions. Series B is represented by overbank facies formed during periods of low water levels (sheetfloods) with intervening episodes of increased energy flow.

\section{Chodorki sites}

There are two sites described from the Rospuda River valley, located near the village of Chodorki (Fig. 10). Site 1 is situated in an erosional undercut of the Rospuda River (on the surface of the upper outwash plain level, elevation $158 \mathrm{~m}$ a.s.1.), whereas site 2 is a small exposure located north of the bridge (on the surface of the lower outwash plain level, elevation $145 \mathrm{~m}$ a.s.1.). Site 1 reveals trough-bedded, horizontally laminated sands, with sporadic interbeds of cross-bedded gravels and sands (5.5 $\mathrm{m}$ in thickness).

Site 2 is represented by cross-bedded sands and gravels with a layer of cross-bedded fine-grained sands (6 $\mathrm{m}$ in thickness).

Interpretation. The river-bank scarp reveals deposits accumulated under more concentrated flow conditions, in the distal part of the outwash plain. They are characteristic of lithotype a deep plane-bed channel with megaripples (Zieliński, 1993).

\section{Szczebra sites}

The Szczebra 1 site is located at the Augustów-Suwałki road. Off the road, slightly to the west, there is the Szczebra 2 site concealed in the forest. Near the gravel-pit, there is the Blizna River flowing - a small tributary of the Rospuda River (Fig. 11). 

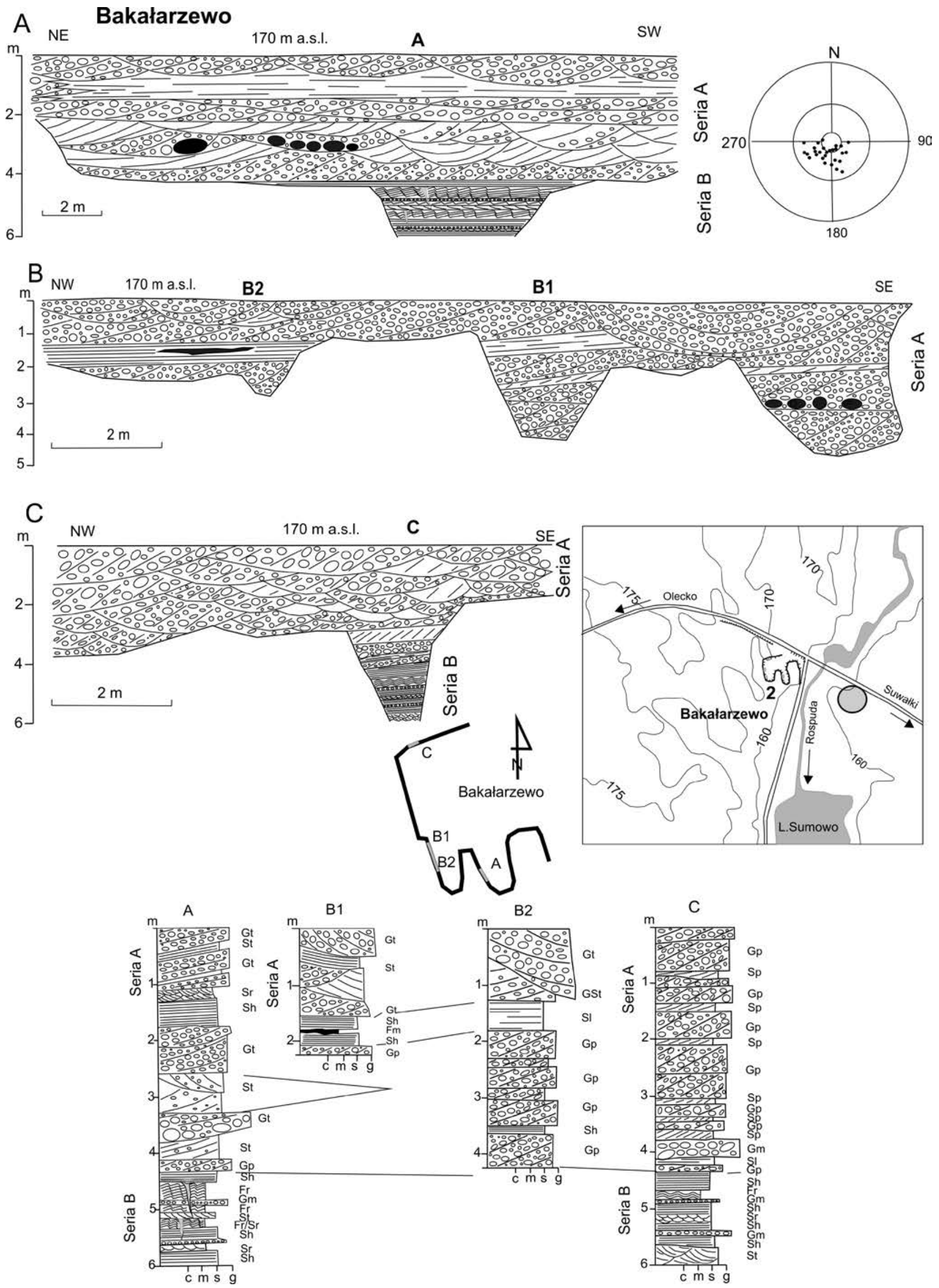

Fig. 5. Location of the Bakałarzewo site, and the sketch-drawings of exposed walls. For explanations see Fig. 3. 


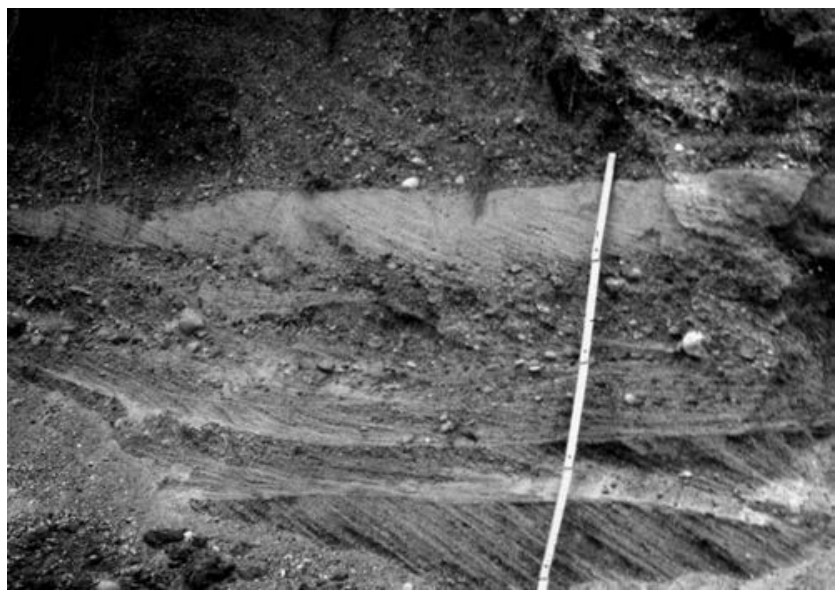

Fig. 6. The Bakałarzewo site exposure. Photo by D. Krzyszkowski

Szczebra 1. The top of the deposits is at an elevation of $132.5 \mathrm{~m}$ a.s.l., and the thickness of the observed section is $8 \mathrm{~m}$. Two series can be distinguished: Upper series A - represented by trough-bedded coarse-grained sands - approximately $2 \mathrm{~m}$ in thickness.

Lower series B - composed of sediments reflecting a decreasing energy of aqueous environment: horizontally laminated sands and ripple cross-laminated sands. An ice-wedge cast, developed down to a depth of $2.5 \mathrm{~m}$, has been described from fine-grained deposits of this series. This wedge, along with an accompanying thin layer of laminated clay, documents a remarkable sedimentary gap. Above the ice-wedge cast, the fine-grained sediments still continue (about $1 \mathrm{~m}$ thick). Series B is underlain by trough-bedded sands and gravels (series C).

Szczebra 2. This section is represented by cross-bedded sands and gravels, passing upwards into horizontally bedded sands (total thickness about $3.5 \mathrm{~m}$; Fig. 11).

Interpretation. The Szczebra 1 site records three stages of sedimentation, from a flow under conditions of deep channel with scour bedforms - series C ( Zieliński, 1993) - to a progressively slower flow finished with deposition of overbank facies and the emergence of part of the water body floor (series B). Under periglacial climate conditions, an ice wedge developed on the emerged surface. It was followed by temporary sedimentation in a low-energy environment. Another episode of increased material supply resulted in the accumulation of coarse series A under conditions of higherenergy flow. The deposits found in Szczebra 2 site represent the top part of series A, observed in the Szczebra 1 site.

\section{ISSUE OF THE LAST ICE SHEET LIMITS}

It has been commonly assumed that the maximum ice-sheet limit was asynchronous in Poland, and took place between 24 and $19 \mathrm{ka} \mathrm{BP}$, occurring later in time in eastern Poland (Marks, 2012). South of the Baltic Depression, there were a few ice streams (lobes) at different stages of the last glaciation development (Marks, 2012). In NE Poland, these were the Masurian and Lithuanian ice streams (lobes) that themselves separated from the main ice stream in the Gulf of Riga (Punkari, 1997; Saarse et al., 2012).

The study area is located in a region covered by the Vistulian Glaciation. The maximum ice-sheet limit during the Main Stadial about $25 \mathrm{~km}$ south of Augustów. It is questionable whether the ice sheet slightly overstepped the Biebrza Valley or just invaded its northern part (Ber, 2000; Krzywicki, 2002; Banaszuk, 1998, 2001; Marks and Karabanov, 2011; Morawski and Lisicki, 2014). Until the early 1990s, apart from stadial-rank ice-sheet limits (Leszno Stadial and Leszno-Pomeranian Stadial), the recessive Pomeranian phase and three sub-phases: Wigry, Hańcza and Szeszupa (Ber, 1967,1982) had been distinguished in the Augustów Plain and Suwałki Lakeland.

Some time later, the next ice-sheet limits were delineated east of the study area (in the Sejny Lakeland), accepting a frontal model of deglaciation of this ice sheet (Lisicki, 1993).

At the initial stage of advance, the Pomeranian Stadial ice sheet of the Vistulian Glaciation was split into the Rospuda Lobe (which was developed within the larger Masurian Lobe/Stream) advancing from the NW (Morawski, 2005), and two distinct ice lobes of Sejny and Wigry, which were developed within the Lithuanian Ice Stream invading from the NNW (Ber and Ryka, 1998; Ber, 2000). The NE-SE-trending Rospuda subglacial channel, with the total length of approximately $40 \mathrm{~km}$, was formed during the processes of erosion and evorsion within the ice mass of the Main Stadial ice sheet of the Vistulian Glaciation. During the Pomeranian Stadial, this landform continued to occur within the ice sheet and discharged meltwater towards the SE at times of ice retreat. It cannot be precluded that its trend was controlled by faults in the basement (Ber, 2000).

In the geological map of Poland, scale 1:500,000 (ed. Marks et al., 2006), the ice-sheet limit in the Pomeranian phase is drawn north of Olecko, towards Raczki and further arcuately towards the NE, crossing the Suwałki-Augustów outwash plain, towards Lake Wigry. In a study on an outwash plain located between Olecko and Rajgród, Krzywicki et al. (2007) discussed the correlation with the above-mentioned sub-phases. The formation of the channel was controlled by the presence of basement faults (Ber, 2000).

The recently conducted studies show that the ice-sheet limit of the Pomeranian phase run near Olecko (Fig. 12; in Stożne - southern slope of the Szeskie Hills; Lisicki et al. 2010) and a moraine located west of Lake Garbaś, towards the SE, i.e. towards the southern part of the Lake Wigry basin (Ber and Pochocka-Szwarc, 2010; Krzywicki and PochockaSzwarc, 2013; Pochocka-Szwarc and Krzywicki, 2014).

Based on the results of dating of erratic boulders, using the ${ }^{36} \mathrm{Cl}$ method (Dzierżek and Zreda, 2007; Dzierżek, 2009), it is thought that the ice sheet melted unevenly in the Suwałki Lakeland area. Ice-free zones may have occurred locally south of Lake Hańcza (near Bachanowo and Kruszki) at about 26 to $28 \mathrm{ka}$, i.e. during the Main Stadial.

The moraines observed near Lake Wigry were formed at about $19.7 \mathrm{ka}$ (Dzierżek and Zreda, 2007) and are correlated with the Pomeranian phase. Dates from around Lake Hańcza suggest that the Łopuchowo moraines were becoming exposed at 17.9 to $14.4 \mathrm{ka}$ (Dzierżek and Zreda, 2007). 

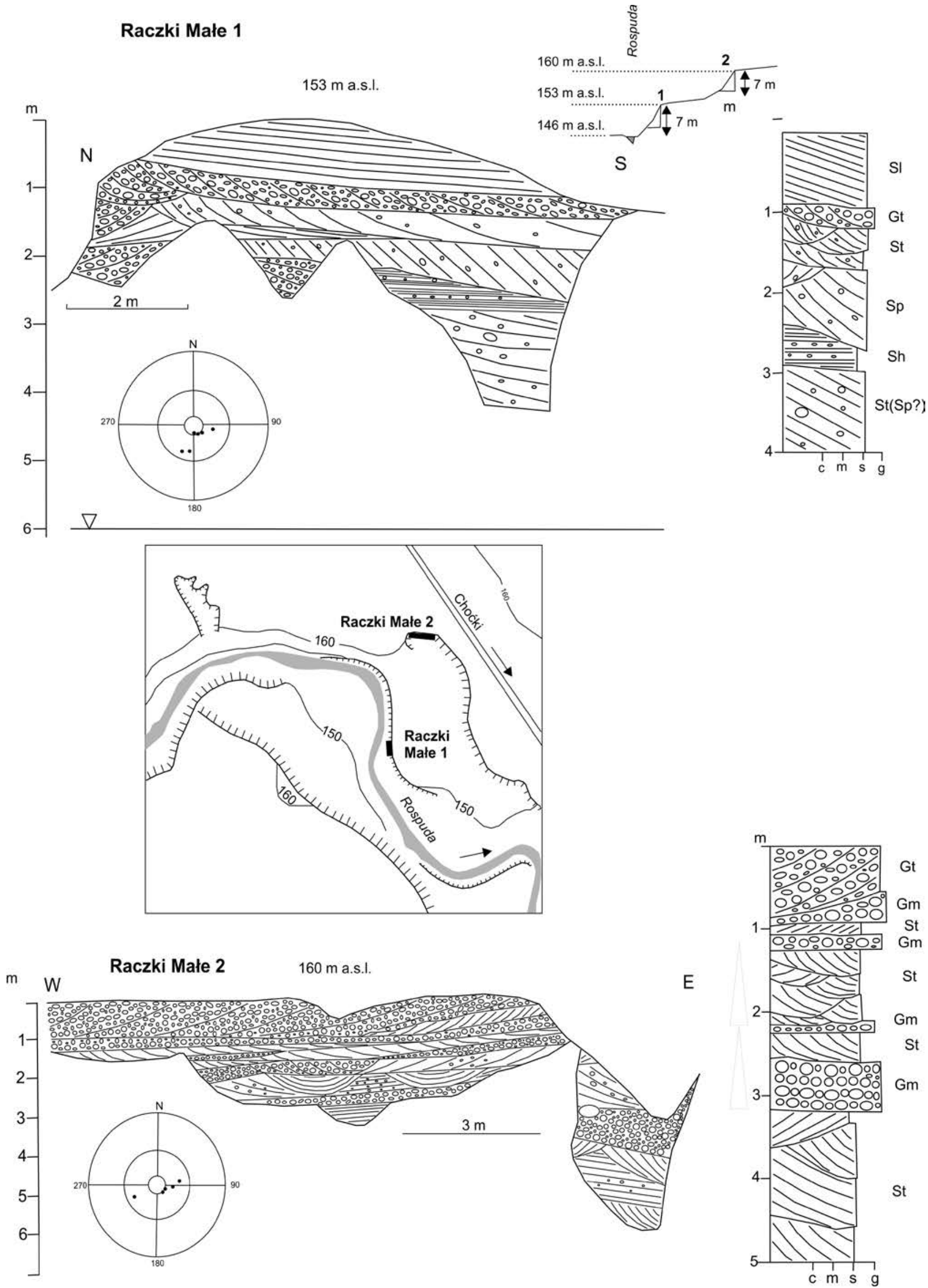

Fig. 7. Sections of the exposures at Raczki Małe. For explanations see Fig. 3. 
Choćki 1

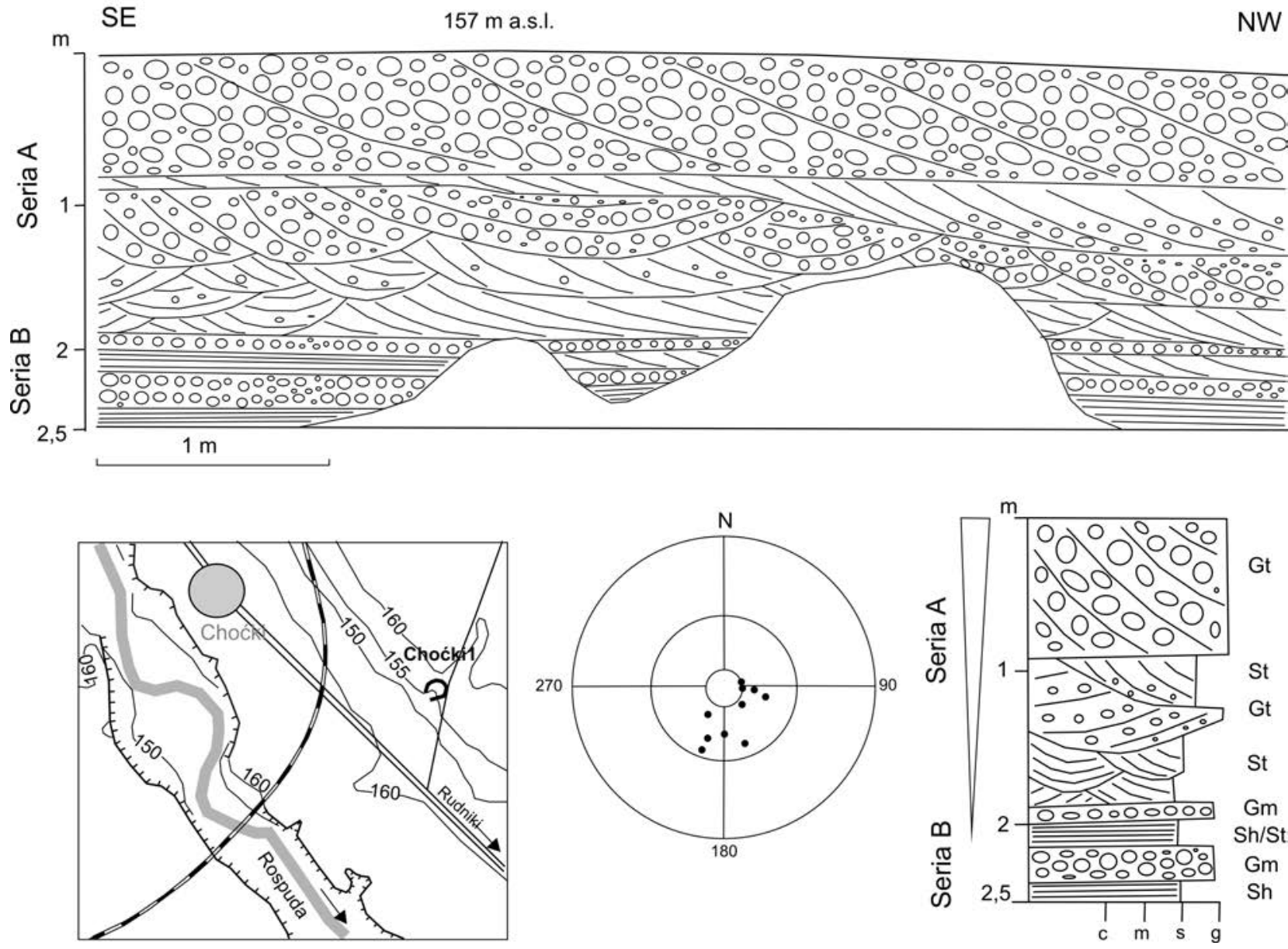

Fig. 8. Location of the Choćki site, and the sketch-drawing of the lithological section. For explanations see Fig. 3.

\section{DISCUSSION}

The northernmost sites: Garbaś and Szafranki, are characterised by similar lithologies indicating deposition in the proximal zone of braided channel near the ice-sheet front. The deposits were accumulated by high-energy flows, close to the meltwater source. The top surfaces of these deposits occur at elevations from 195 to $170 \mathrm{~m}$ a.s.1. These sites are found in the northern sector of the Rospuda River valley. The close meltwater source, represented by the ice-sheet snout, stretched along the line of terminal moraines extending west of Lake Garbaś. The moraines were previously correlated with the ice-sheet limit of the so-called Hańcza phase (Lisicki, 1993) - one of several recessive sub-phases of the Pomeranian phase.

This limit is currently correlated with the line of end moraines of the Pomeranian phase (Marks et al., 2006). It is drawn south of Lake Bolesty, and westwards to the Stożne area (on the southern slope of the Szeskie Hills). In that area, there is an ice-marginal zone along with a subglacial tunnel mouth releasing meltwater towards the south (Lisicki et al., 2010; Fig. 13). Thus, the melting water from the ice was rechargeding a proglacial concentrated flow recorded at the Garbaś, Szafranki oraz Bakałarzewo sites. Large-scale bars deposited under conditions of concentrated flow have been documented in the central sector of the outwash plain near Raczki Małe and Choćki (top at an elevation of approximately $160 \mathrm{~m}$ a.s.l.) and the gravel-bed braided river (Szkocja site, $155 \mathrm{~m}$ a.s.l.). The flowing-water sediments are underlain by facies of low-energy environments, represented by series $B$.

Worth noting is the Bakałarzewo site: there are two horizons with ice-wedge casts in fine-grained stagnant-water deposits (at elevations of approximately 167 and $165 \mathrm{~m}$ a.s.1.) These ice-wedge casts are found in muds and fine-grained sands. In Bakałarzewo, at an elevation of about $170 \mathrm{~m}$ a.s.l., Ber (1974) reported the occurrence of an ice-dammed lake series filling a depression in the subglacial channel and underlying glaciofluvial sediments (Fig. 13). The ice-dammed lake series was supposed to occur before the ice-sheet advance of the Pomeranian phase (Ber, 1974). Thus, it cannot be precluded that the ice-wedge casts in series $\mathrm{B}$ date a break in lacustrine sedimentation in front of the ice sheet.

The sites located in the southern part of the Rospuda outwash plain exhibit also deposits of series B accumulated in stagnant water, occasionally even with episodes of increased coarse material supply (Choćki site). The top of series $\mathrm{B}$ occurs at elevations of $153-150 \mathrm{~m}$ a.s.l., with the 

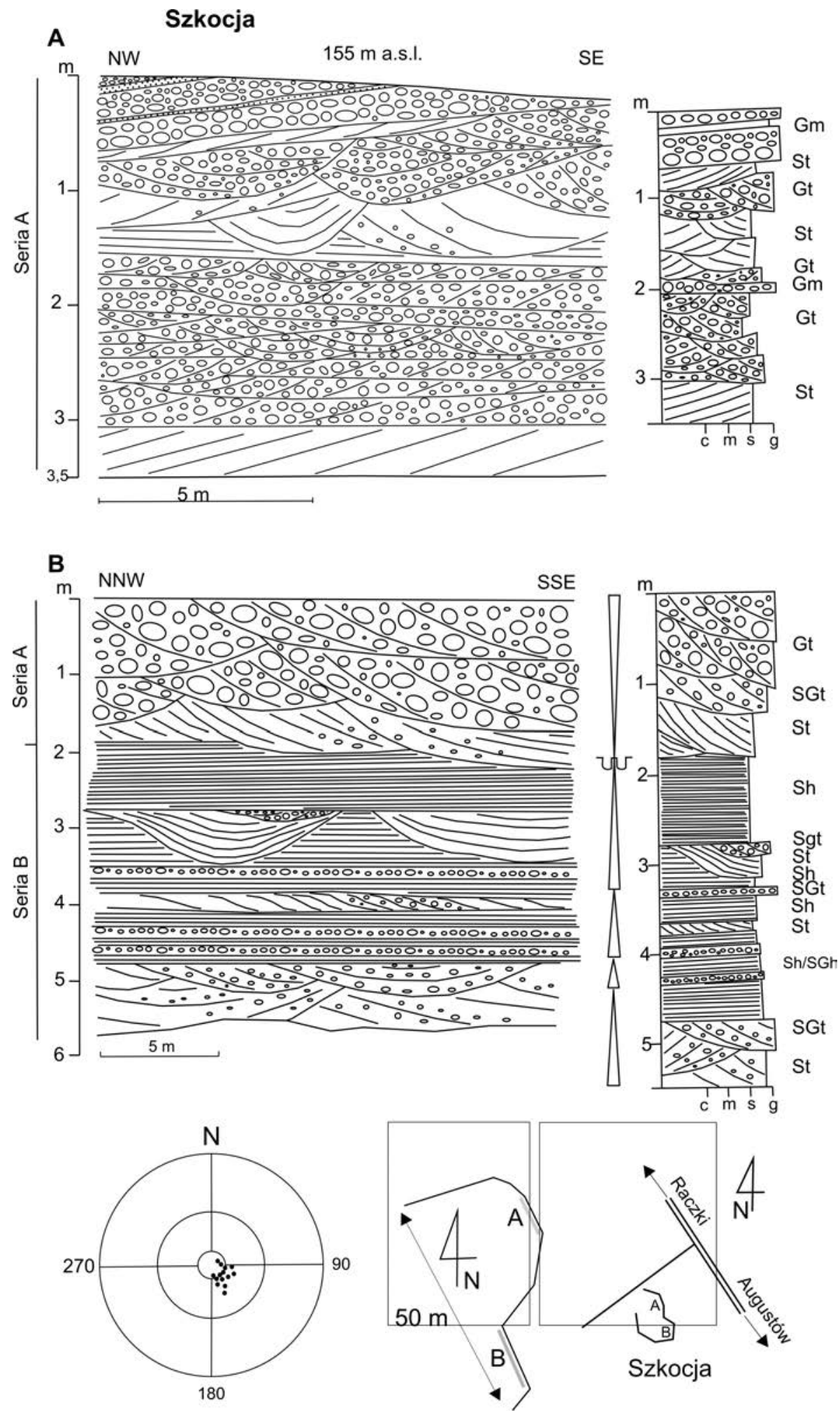

Fig. 9. Lithological sketch-drawing of the exposed wall, lithological section, and diagram of directional structures measurements. For explanations see Fig. 3.

lowest elevation at Szczebra - $130 \mathrm{~m}$ a.s.l. At Szczebra, this is a well-visible horizon suggesting that the water body floor emerged to the surface, and periglacial conditions operated undoubtedly in the presence of permafrost.

Along the subglacial channel, and locally near its edges, occur numerous crevasse-fill landforms and eskers (Bruj and Woźniak, 1991; Ber, 1991, 2007). Longer axes of these land- forms are consistent with the channel trend. They are composed of winnowed medium- and coarse-grained sands overlain by an about 1-m-thick silty, sand-gravelly layer. This situation may indicate deposition in ice crevasses, where an episode of concentrated flow was followed by the accumulation of morainic mud layer. 

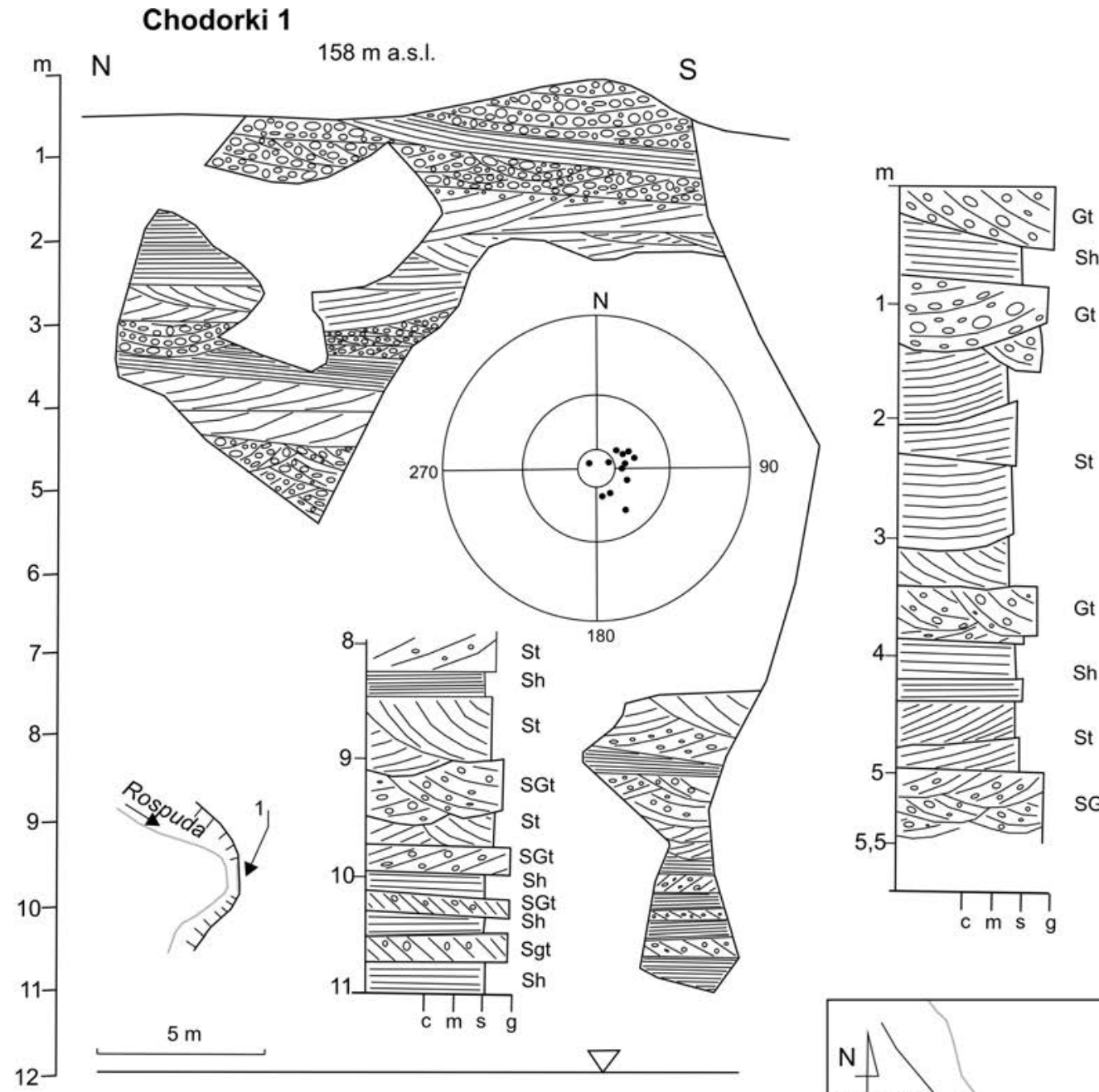

\section{Chodorki 2}

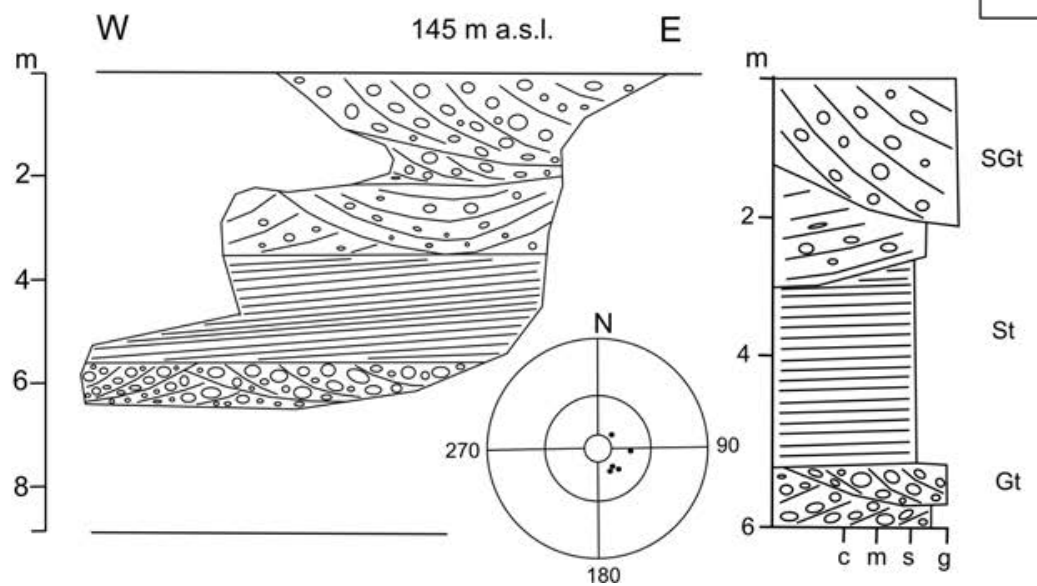

Fig. 10. Location of the Chodorki site, lithological sketch-drawing of the exposed wall, lithological section, and diagram of directional structures measurements. For explanations see Fig. 3. 

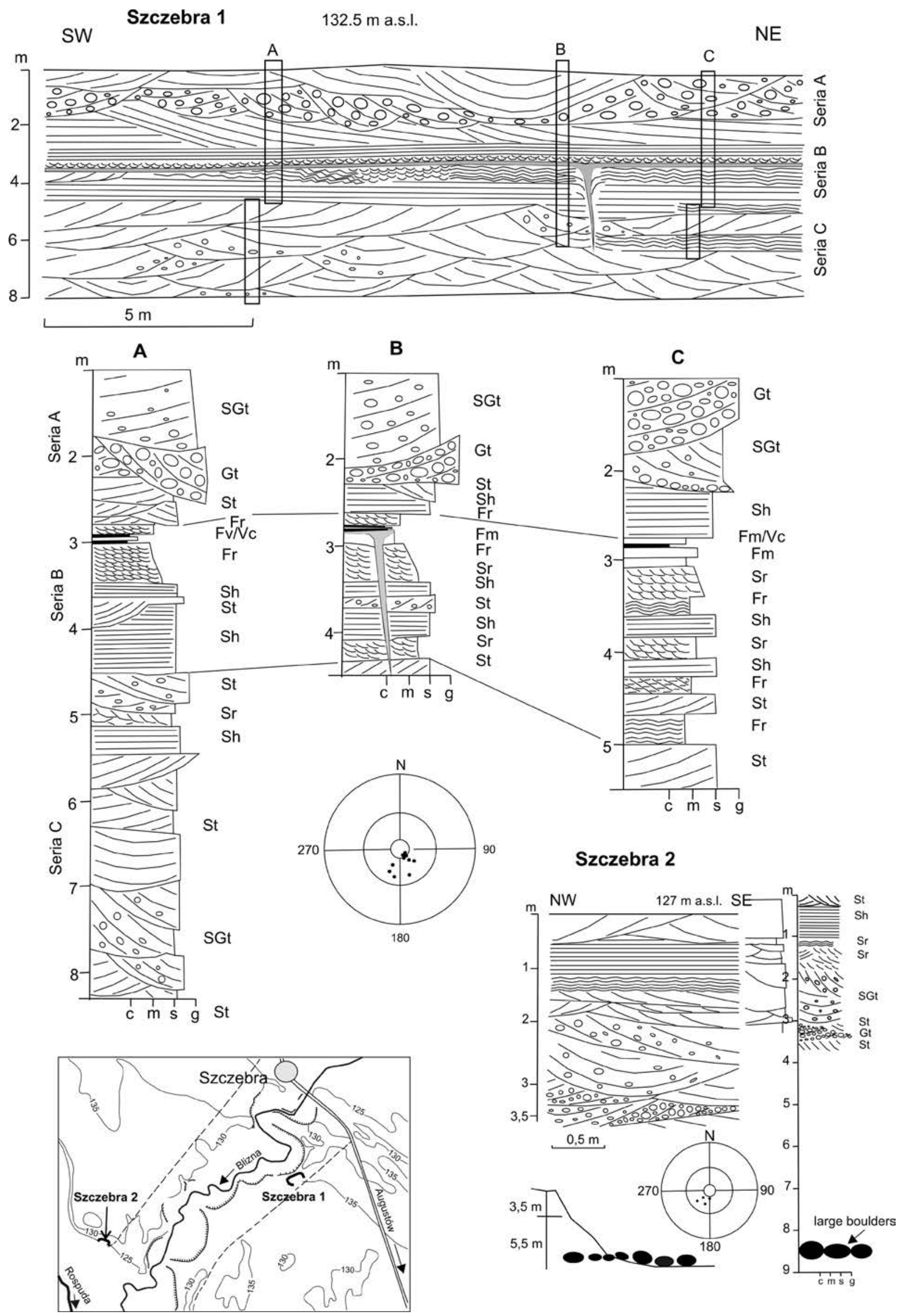

Fig. 11. Location sketch-map of the Szczebra 1 and Szczebra 2 sites with lithological sections of exposed walls. For explanations see Fig. 3. 


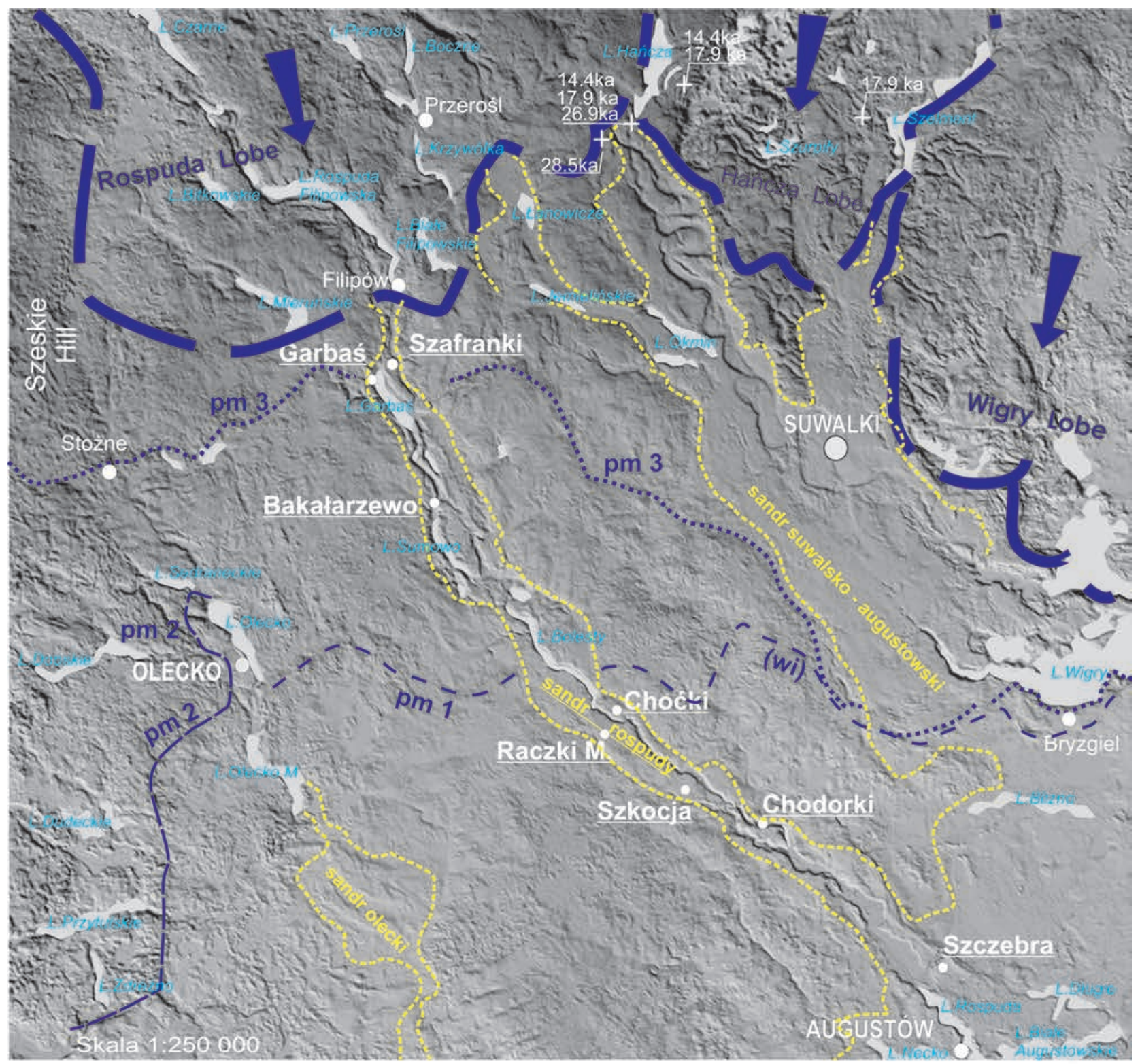

Explanations:

\begin{tabular}{|c|c|c|}
\hline $\begin{array}{l}\text { pm } 1 \\
\text { (wi) }\end{array}$ & - - & $\begin{array}{l}\text { Recesional sub-phases like: wi - Wigry sub-phases, } \\
\text { after Ber 1967, Lisicki } 1993\end{array}$ \\
\hline pm 2 & - & Ice - sheet limit - Pomeranian phase, after Krzywicki at all 2007 \\
\hline \multirow[t]{4}{*}{ pm 3} & $\cdots$ & $\begin{array}{l}\text { Ice - sheet limit - Pomeranian phase, after } \\
\text { Krzywicki, Pochocka-Szwarc 2013; }\end{array}$ \\
\hline & & Outwash plain outline \\
\hline & $=$ & Ice sheet movement after Ber, Ryka 1998; Morawski 2005 \\
\hline & & Glacial lob after Ber, Ryka 1998, Ber 2000 \\
\hline Shoćki• & & Investigation site \\
\hline $\begin{array}{l}17.9 \mathrm{ka} \\
+\end{array}$ & & $\begin{array}{l}\text { Cosmogenic } 36 \mathrm{Cl} \text { dating of glacial boulder } \\
\text { after Dzierżek, Zreda } 2007 \text {. Dzierżek } 2009\end{array}$ \\
\hline
\end{tabular}

Fig. 12. The Rospuda and Suwałki-Augustów outwash plains, and the ice-sheet limits compiled according to various authors. 


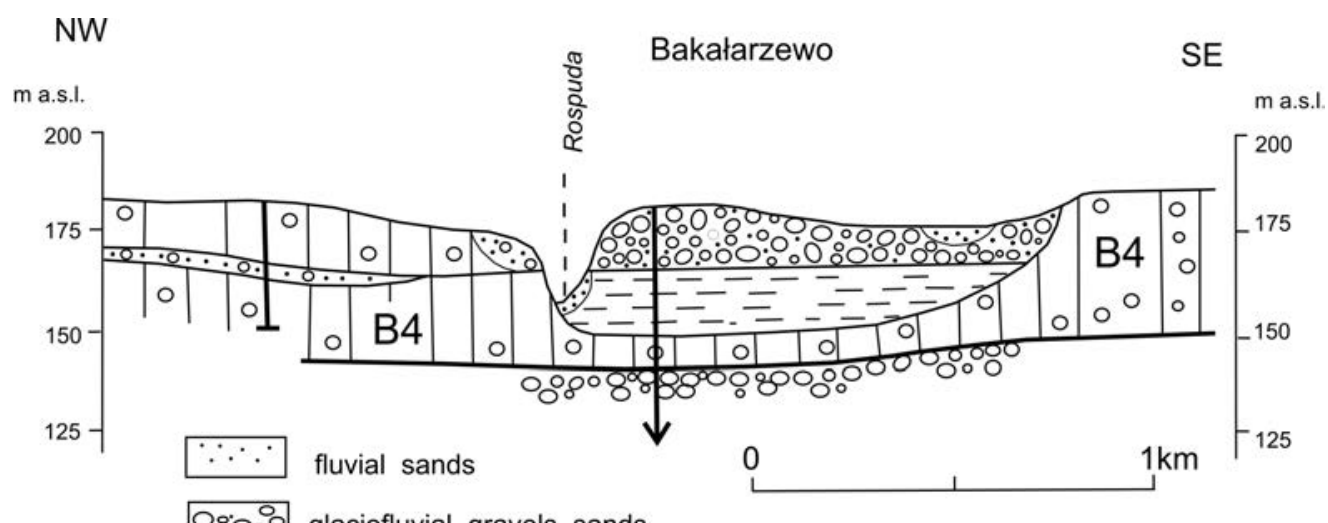

9.:००: glaciofluvial gravels, sands

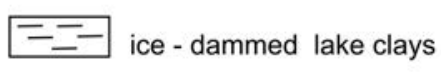

B4 - Vistulian Glaciation

O

borehole

Fig. 13. Geological cross-section through the Rospuda valley near Bakałarzewo, after Ber, 1974.

\section{CONCLUSIONS}

Based on the sites studied, it has been found that the meltwater flow in the Rospuda outwash plain was braided in nature with predominance of proximal lithofacies in the northern part, and distal lithofacies towards the south. The identified lithotypes correspond with those of some outwash plains from NE Poland, studied by Zieliński (1993).

Series A has been identified, and it differentiates into proximal environment lithofacies (Bakałarzewo and Chocki sites) and more distal lithofacies (Szkocja, Chodorki and Szczebra 1 sites). The deposits of series B (overlaing series A), found in the Bakałarzewo, Szkocja and Szczebra sites, represent a stagnant-water environment, or with a slight flow. The water body floor was periodically exposed to the surface. Under periglacial conditions, ice-wedges developed.

Two levels have been distinguished within the Rospuda outwash plain trail:

- lower level, erosional-accumulative in nature (elevations from $187 \mathrm{~m}$ a.s.l. in the north, to $144 \mathrm{~m}$ a.s.l. in the central part, and about $130 \mathrm{~m}$ a.s.l. in the south),

- upper level, erosional in character (elevations from 198 to $170 \mathrm{~m}$ a.s.l. in the north, and $150 \mathrm{~m}$ in the central part). Its surface is covered by a pavement of gravelly-sandy, frequently silty, sediments.

The Garbaś and Szafranki sites document the proximal zone of the outwash plain, close to the recharge source represented by the ice-sheet front still standing along the line Stożne-Garbaś and further southeast towards Lake Wigry (Fig. 12). This line can be correlated with the ice-sheet limit of the Pomeranian phase of the Vistulian Glaciation (Ber and Pochocka-Szwarc, 2010)

Due to lack of dating of series B adsolute time age, the timing of emergence of the stagnant-water sediments cannot be determined - it took place certainly prior to the deposition of braided sediments. The series B can be correlated with the ice-dammed lake series from Bakałarzewo (Fig. 13), deposited before the ice-sheet advance of the Pomeranian phase (Ber, 1974).
Compared to the Rajgród-Olecko outwash plain (Krzywicki et al., 2007), glaciofluvial deposits of the Rospuda outwash plain are attributed not the same ice-marginal zone.

\section{Ancknowledgments}

This research was supported by Polish Geological Institute, Regional Coordinatory Team of the DGM of Poland in scale 1:50,000. Special thanks go to prof. Andrzej Ber for his support in the field research.

\section{REFERENCES}

Banaszuk, H., 1998. Zasięgi i przebieg zlodowacenia Wisły i Warty w północno - wschodniej Polsce w świetle nowych badań. w: Główne kierunki badań geomorfologicznych w Polsce. UMCS Lublin.

Banaszuk, H., 2001. Zasięg zlodowacenia Wisły w Polsce północno-wschodniej na podstawie badań geomorfologicznych i termoluminescencyjnych. Przegląd Geograficzny 73, 3, 281305.

Ber, A., 1967. Szczegółowa mapa geologiczna Polski w skali 1:50 000 ark. Jeleniewo. Mat. NAG PIG-PIB.

Ber, A., 1974. Czwartorzęd Pojezierza Suwalskiego w: Z badań Czwartorzędu w Polsce. Biuletyn PIG 15, 269, 23-94.

Ber, A., 1982. Marginal zones and deglaciation during the North Polish Glaciation in the Suwałki - Augustów Lakeland. Biull. Inst. Geol. 343, 71-89.

Ber, A., 1989. Morfogeneza Pojezierza Suwalskiego i Równiny Augustowskiej. Studia i Mat. Ocean. 56. Geologia Morza (4), 191-207.

Ber, A., 1991. Szczegółowa mapa geologiczna w skali 1:50 000, ark. Augustów. Mat. NAG PIG-PIB.

Ber, A., 2000. Plejstocen Polski północno-wschodniej w nawiązaniu do głębszego podłoża i obszarów sąsiednich. Prace PIG CLXX, 5-84.

Ber, A., 2007. Objaśnienia do Szczegółowej Mapy Geologicznej w skali 1:50 000 ark. Augustów. Mat. NAG PIG-PIB.

Ber, A., Ryka, W., 1998. Influence of the crystalline basement on the sedimentary cover of the ekstern part of the peribaltic dpresionnion, Poland. In: Geology of the suwalki anorthosite massif NE Poland. Prace PIG CLXI, 171-181.

Ber, A., Pochocka-Szwarc, K., 2010. Suwalszczyzna-jeszcze raz o 
zasiegach ladolodu zlodowacenia Wisły. Mat. XVII Konf. Stratygrafia Plejstocenu Polski. Jeziorowskie 2010, 51-52, ISBN 978-83-7538-654-7

Bogacki, M., 1976. Współczesne sandry na przedpolu Skeidararjokull (Islandia) i plejstoceńskie sandry w Polsce północnowschodniej. Rozprawy UW 93.

Bruj, M., Woźniak, P., 1991. Objaśnienia do Szczegółowej Mapy Geologicznej w skali 1:50 000 ark. Olecko. Mat. NAG PIG-PIB.

Dzierżek, J., 2009. Paleogeografia wybranych obszarów Polski w czasie ostatniego zlodowacenia. Acta Geographica Lodziensia $95,1-112$

Dzierżek, J., Zreda, M., 2007. Timing and style of deglaciation of northeastern Poland from cosmogenic ${ }^{36} \mathrm{Cl}$ dating of glacial and glaciofluvial deposits. Geological Quarterly 51 (2), 203216.

Krzywicki, T., 2002. The maximum ice sheet limit of the Vistulian Glaciation in northeastern Poland and neighbouring areas. Geological Quarterly 46 (2), 165-188.

Krzywicki, T., Smolska, E., Szwarczewski, P., 2007. Etapy rozwoju sandru olecko-rajgrodzkiego na tle faz recesyjnych zlodowacenia Wisły w nawiązaniu do wybranych cech strukturalno-teksturalnych osadów. Słupskie Prace Geograficzne 4, 79-92.

Krzywicki, T., Pochocka-Szwarc, K., 2013. Geologiczno-środowiskowe warunki utworzenia geoparku „Kanał AugustowskiAugustowskie Sandry". NAG PIG-PIB Warszawa

Krzyszkowski, D., 1993. Pleistocene glaciolacustrine sedimentation in a tectonically active zone, Kleszczów Graben, central Poland. Sedimentology 40, 623-644.

Lisicki, S., 1993. Czwartorzęd Pojezierza Suwalskiego. Przwodnik LXIV Zjazdu PTG. Suwałki 1993

Lisicki, S., Szynkaruk, E., Kacprzak, L., Terpiłowski, S., Godlewska, A., 2010. Osady akumulacji szczelinowej w strefie marginalnej lądolodu fazy pomorskiej. Mat. XVII Konf. Stratygrafia Plejstocenu Polski. Jeziorowskie 2010. ISBN
978-83-7538-654-7

Marks, L., 2012. Timing of the Late Vistulian (Weischelian) glacial phases in Poland. Quaternary Science Reviews 44, 81-88.

Marks, L., Ber, A., Gogołek, W., Piotrowska, K., 2006. Geological map of Poland in scale 1:500 000. Wyd. PIG ISBN 83-7372-853-8

Marks, L., Karabanov, A., 2011. Mapa Geologiczna północnej części obszaru przygranicznego Polski I Białorusi 1:250 000. Państw. Inst. Geol. - Państw. Inst. Bad. Warszawa

Miall, A.D., 1977. A review of the braided river depositional environments. Earth Sciences Reviews 13, 1-62.

Miall, A.D., 1996. The Geology of Fluvial Deposits: Sedimentary Facies, Basin Analysis and Petroleum Geology. SpringerVerlag, Berlin, 79.

Pochocka-Szwarc, K., Krzywicki, T., 2014. Geomorfologia, powierzchniowa budowa geologiczna oraz zasięg lądolodu stadiału głównego zlodowacenia Wisły w rejonie Wzgórz Sokólskich, Kotliny Biebrzańskiej i Równiny Augustowskiej. Mat. XXI konf. Stratygrafia Plejstocenu Polski. Augustów 2014, 51-52; ISBN 978-83-7863-382-2

Punkari, M., 1997. Glacial and glaciofluvial deposits in the interlobate areas of the Scandinavian ice sheet. Quaternary Science Reviews 16, 741-753.

Saarse, L., Heinsalu, A., Veski, S., 2012. Deglaciation chronology of the Pandivere and Palivere ice-marginal zones in Estonia. Geological Quarterly 56 (2), 353-362.

Morawski W., 2005 - Reconstruction of the ice-sheet movement from the orientation of glacial morpholineaments an example from NE Poland. Geological Quarterly 49 (4), 403-416.

Morawski, M., Lisicki, S., 2014. Forma kamienia. Paleogeografia „wyspy” morenowej Sztabina w czasie zlodowacenia Wisły. Mat. XXI konf. Stratygrafia Plejstocenu Polski. Augustów 2014, 162-169; ISBN 978-83-7863-382-2

Zieliński, T., 1993. Sandry Polski północno-wschodniej: osady i warunki sedymentacji. Wyd. U. Śląski 